\title{
Changing fortunes? Aspiration and realisation for looked after young people's post-compulsory educational pathways in England
}

\author{
Claire Cameron UCL Institute of Education, UK \\ c.cameron@ucl.ac.uk
}

(Received February 2017

Revised October 2017)

http://dx.doi.org/10.14301/Ilcs.v9i1.451

\begin{abstract}
The post-compulsory educational pathways of young people who have spent some or all of their childhoods in local authority care varied. They are seven times less likely to attend university than their age contemporaries not in care. Even those with some qualifications at age 16 face difficulties in progression. Based on the English data from a European study of young people with a public care background, this paper sets out six pathways and investigates whether and how young people's aspirations and goals for the short term were realised. The paper argues that among this group of young people who were in local authority care the dominant positioning is of self-responsibility for achieving plans, in line with individualist thinking. But such positioning is an overly optimistic picture; many barriers to the realisation of plans were also evident.
\end{abstract}

\section{Keywords}

Care leavers; aspirations; educational pathways

\section{Introduction}

Continuing in post-compulsory education is an effective protective factor for care leavers entering adult life, but, even for those with apparent 'educational promise' it is not always realised. Since 2000, the Department for Education (England) has introduced successive policy measures to address acute educational disadvantage for young people in and leaving public care including making the promotion of educational attainment of children in its care a statutory duty of local authorities (Children Act 2004), making the admission of children in care to schools for which they are suitable a priority (Children Act 2008), giving a senior official responsibility for looked after children's attainment in each local area via a 'Virtual School' and enabling young people to 'stay put' in successful foster placements post 18
(Children and Families Act 2014). In 2016, the government Care Leavers Strategy reiterated that reaching one's full potential was a key policy ambition for care leavers 'whether that is going to college or university, taking up an apprenticeship or getting a skilled job' (DfE, 2016: p30).

But the disparity between the educational attainments of children aged 16 who have been in local authority care for at least 12 months and those who have not been in care remains stark. In $2016,17.5 \%$ of children in care achieved an officially described 'good' level of educational qualifications (five GCSEs graded $A^{*}-C$ ) at age 16, compared to $58.8 \%$ of children who had not been in care (DfE, 2017). Furthermore, $7 \%$ of young people who had left care and were in touch with their local authorities and aged 19-21 years were in higher 
education, defined as studies beyond upper secondary (A level in England) (DfE, 2017), compared with about $48 \%$ of all young people (DfE, 2016). These figures indicate that the upper secondary education phase is particularly problematic, yet, as Geiger and Beltran (2017) point out, most young people in care aspire to attend college, and 19-year-old ex-fostered Californians are optimistic about their futures (Courtney et al., 2016).

Educational participation and success are structured by parental background (Desforges \& Abouchar, 2003), closely associated with social class (Halsey, Heath \& Ridge, 1980). As children who are looked after largely come from the most disadvantaged socio-economic backgrounds (Bebbington \& Miles, 1989) low levels of educational qualifications might be expected. Children who are 'in need' of additional support but are not looked after in care in England do worse, educationally, at age 16, than those in care (Sebba et al., 2015). Children from low socio-economic status family backgrounds are much less likely to attend universities, particularly high-status universities, but differences in academic achievement do not explain all the variance, suggesting other factors are at play (Jerrim, und).

The ways in which young people position themselves in relation to their futures, their sense of their own possibilities and their capacities to lead changes in their lives is significant in explaining choice-making in relation to education. Furlong (2009) argues that the link between social class and education is highly influenced by individualist rather than class-based orientations. Young people seek individual solutions that are still clearly class related but "this does not signal the death of class or invalidate approaches that utilise information on structural location as a way of understanding outcomes, nor does it suggest that young people lack an awareness of the link between resources and life chances" (Furlong, 2009: 349). The individualisation thesis (Beck \& Beck-Gernsheim, 2002) argues that instead of fulfilling preordained social categories or following traditions associated with church, family or state, young people are increasingly shaping, and held to be responsible for shaping, their own biographies, with adherence (or not) to multiple reference groups, with multiple options. The 'freedom' that comes with selfresponsibility is accompanied by 'risks' such as a lack of certainty about one's choices and who reliable others might be. Care leavers and their educational pathways might be seen as an acute case of individualisation. More or less cast adrift by the welfare system at age 18 or 19 , just at the point when their age contemporaries are entering higher education, and in the context of insecure employment-based alternatives, how do they consider their options and what decisions do they take? Explanations for care leavers' access to and success in post-compulsory education are clearly structured by their origins, not just in relation to family of origin (Berridge, 2017) but also in relation to gender, race and ethnicity, as well as former 'in care' status (Geiger \& Beltran, 2017). Care leavers often have delays in acquiring qualifications, multiple responsibilities and demands on them as well as a high degree of personal motivation (Jackson \& Cameron, 2014). They exercise agency and show resilience (Berridge, 2017; Harvey, Campbell, Andrewartha, Wilson \& Goodwin-Burns, 2017).

\section{Study aims and method}

This paper offers a critique of the individualisation thesis from the perspective of care leavers in England. Realising ambition for care leavers is a complex process involving individual determination as well as familial and structural barriers and facilitators. The aim is to track the changing fortunes of a group of young people leaving care who had been selected for having educational promise at age 16. The data are drawn from the EU-funded 'Young People from a Public Care Background: pathways to further and higher education in Europe' (known as YiPPEE) that took place from 2008 to 2010 in Denmark, Hungary, England, Spain and Sweden. This paper reports on data from England but the thematic findings are similar in the partner countries. The first of its kind in Europe, the study was a mixed methods design including national and local analyses of policy and practice and secondary analysis of large scale data sets as well as biographical narrative interviews with a total of 170 young people aged 18-24 years and with adults selected by the young people as having made a difference to their educational lives. Interviews with young people took place at two time points, approximately one year apart in order to track the realisation of their educational trajectories and the barriers and facilitators that frame those trajectories, inspired by the qualitative 
longitudinal biographical approach of Henderson, Holland, McGrellis, Sharpe \& Thomson (2007). Using a biographical approach that included constructing a timeline, we gathered data on present and past lives in relation to birth and alternative families, care placements, school, outof-school activities, personal relationships and friendships, employment, voluntary work, health, housing and criminal activity. The interviews started with an invitation to talk about 'current concerns' and ended with a section on 'hopes and dreams', when participants were asked about their aspirations for their future lives in one and five years' time.

Recruitment in England was difficult and protracted as is common with this group of young people (Berridge, 2017; Wigfall \& Cameron, 2006). We asked leaving care teams in five local areas with contrasting socio-economic characteristics to nominate young people as potential participants. Eligibility criteria for educational promise were set at having at least one GCSE pass that would enable the young person to progress in further education but even with this low bar nominations from leaving care teams were few. Ethical procedures in place at the coordinating institution, the UCL Institute of Education, were followed, using 'opt in' informed consent explicitly allowing for withdrawal of participation at any time. Young people were offered a financial 'thank you' voucher of $£ 20$ for their time and expertise. Only 32 of the target 35 could be recruited in the timeframe ( 17 female, 15 male). At follow up one year later (T2), 23 of the original sample could be traced. The second interview, held by phone, was shorter, and focused on the present, the last year, and the future. In this interview, young people were asked to evaluate the realisation of plans and about their own role in, and control over, what had happened. Another 'thank you' voucher was sent. Participants chose their own pseudonyms, used here.

With information at two time points and, with young people's detailed accounts, this is a pragmatic longitudinal study. The case for a longer term, prospective study of English care leavers is still there; secondary analysis of cohort studies give us important but retrospective data (Cameron et al., submitted) while we do not have an equivalent to CalYouth, a large scale study with repeat follow ups (Courtney et al., 2016).
For the current paper, data from the young people will be examined at $\mathrm{T} 1$ and $\mathrm{T} 2$. The main analytic focus is whether, and the extent to which, aspirations voiced at T1 were realised at T2. Earlier analyses presented project data in terms of six pathways through post-compulsory education based on T1 data (Hauari with Cameron, 2014). Each pathway clustered a wide range of contextual, individual and structural barriers and facilitators (Ball, Maguire \& Macrae, 2000), including the extent to which study participants saw possibilities for themselves, termed 'horizons for action'. Young people's horizons could be 'limited' such as ambitions being confined to the immediate vicinity such as the local shop or college, or 'extended', which was when young people imagined themselves in the abstract such as travelling overseas or going to university far away from their home town (Ball et al., 2000). We adopted Ball et al.'s categories and introduced two new ones: 'alternative traditional' and 'building a life' to suit the particular experiences of unaccompanied asylum seekers in our sample.

The present paper will build on the pathway analysis and show what happened to the young people between $\mathrm{T} 1$ and $\mathrm{T} 2$ from the perspective of individualisation and self-talk about futures. At T1, 25/32 participants were in education, of which 12 were in higher education. Nine of this group also had some employment and two of the remaining seven were in full-time work. Ten were unaccompanied asylum seekers and sought asylum on arrival in the UK. Twenty-six were living on their own or with a partner and just three were living with a foster family. Thirteen had contact with their birth family and two reported support from an adviser. Six reported health problems. Support with education was rare from birth families and many had suffered a parental bereavement. Seventeen young people cited at least one care placement that had been unsupportive. Where foster care worked well, it was an extremely important facilitator of educational aspirations (Cameron, Jackson, Hauari \& Hollingworth, 2012). 


\section{Pathways through post-compulsory education}

The main pathway dimensions were: educational activity; practical and emotional support; immigration status; employment; health and/or caring responsibilities; informal learning; and horizons for action. We named the six pathways:

i) Traditional A levellers: ten young people (seven women, three men) who had taken $A$ levels and were either at university or had a firm offer of a university place (all bar three had incurred some delays along the way). Aiming at graduate-level jobs, most had some experience of informal learning through voluntary work and/or employment while a student.

ii) Alternative traditional: six young people (four women, two men) who had arrived in England as unaccompanied asylum seekers and joined schools too late for the full two-year GCSE course but had navigated their way through a range of qualifications and were en route to or in higher education. Aspirations blocked by not holding the right to work or live in the UK indefinitely as adults.

iii) Ordinary young lives: two young women who were academically able but whose commitment to home communities, families and non-academic interests made higher education less important.

iv) Futures on hold: six young people (four women, two men) for whom poor health, bereavement, or caring responsibilities had had a lasting impact on their educational plans. Constant shifts between crisis and stability in their home lives.

v) Home-based locals: four young men who were not in employment or education, and whose horizons for action were highly localised. Strong attachment to their mothers, despite difficult relationships, few or no peer relationships or informal learning interests.

vi) Building a life: four young men who had arrived as unaccompanied asylum seekers, held few educational qualifications and whose ambition was limited by a lack of competence in English, and by their immigration status, but who held a quiet determination to establish themselves.

Despite the diversity of pathways, only two, 'Traditional A levellers', and 'Ordinary young lives' were secure in their orientation to their own futures: for the rest, structural factors such as access to citizenship or the right to work, or employment, or familial or individual factors such as health and caring commitments, acted as barriers to their ambitions. Second, although the sample was more or less equally composed of men and women, men were much more commonly found in the four less secure pathways (12/15 men were represented across 'Alternative traditional', 'Futures on hold', 'Home-based locals' and 'Building a life'). Young people who arrived in the UK as unaccompanied asylum seekers, particularly males, are over-represented in this sample, and the insecurity of immigration status was a dominant theme of their accounts. Third, nearly all the young people engaged with the idea of learning as a route to securing their own futures (less so among 'Home-based locals'). As most participants were in education at the time of interview this may not be surprising. But until recently, care leavers were assumed to be academically unambitious (Jackson \& Sachdev, 2001. Having set out the heterogeneity of this group of care leavers, the next sections discuss the young people's aspirations at T1 and achievements at $\mathrm{T} 2$.

\section{Self-talk about futures at T1}

Study participants had modest and practical future aspirations in line with Brannen and Nilsen (2002). Asked about hopes and dreams for the next year, education was identified as key to the realisation of their hopes for other areas of their life such as employment, financial security and accommodation:

"If I don't go for further studies there's no way I will be able to support myself and my son. So having education is so important." [Sheila, age 23, female, Black Ugandan, Alternative traditional]

Those in education wanted to continue and complete their courses. Eight young people hoped to have started a degree course and a further four planned a further education course within a year of interview. Their past achievements and current progress suggested this was a realistic goal. Other goals held at $\mathrm{T} 1$ interviews were to find employment, either temporary or part time, to fit in with study or home commitments, or full time; more suitable accommodation; three wanted to continue to be in fulfilling personal relationships; four wanted to travel, as part of, or as a planned break from, studies; and six wanted to learn to drive.

In five years' time, 23 participants aspired to have a full-time job that was stable; a so-called 'good' job that they would find fulfilling. Ongoing 
learning was a major route towards achieving this goal. Thirteen study participants cited education and achieving further qualifications as part of their five-year ambition. In five years' time, ten young people wanted to be living in their 'own' house, in a 'nice', 'safe' area, supported by a mortgage. Several young people talked about their frustrations of living with birth family or in shared accommodation and of how much they wanted to achieve independence not just in terms of their own space but also not having to rely on financial support from the local authority for housing. Having children, lasting personal relationships and fulfilling leisure pursuits were not generally seen as realistic in the next five years. They wanted what they referred to as what 'ordinary' people have, a good career or stable employment, financial security, their own accommodation. Five young people specifically stated that they did not want to have children at all in the future.

Overall, self-talk about futures at T1 focused on completion of education and securing employment, despite the delays, competing commitments and structural barriers they faced (Hauari with Cameron, 2014).

\section{Self-talk about achievements and aspirations at $\mathrm{T} 2$}

At $\mathrm{T} 2$, ten young people were enrolled on or just finishing a BA degree course (seven 'Traditional A levellers' and three 'Alternative traditional'), one was doing an NVQ Level 3 award ('Ordinary young lives'), and another on a Level 2 BTEC Diploma course ('Building a life') (both of the last two were being carried out alongside employment). Eight had a main activity of employment, such as in a restaurant, a garage, as an assistant gardener, stacking pallets on nightshifts, a shop assistant, preschool assistant, childminder and in a school (drawn from across all pathways). Four were unemployed: of these, one woman was a hospital inpatient, one was a full-time mother, and two were looking for work (male) ('Futures on hold', 'Home-based locals' and 'Building a life'). Four of those on BA programmes or about to finish them had part-time work alongside their studies and four were doing voluntary work. However, focusing on main activity neglects the complexity of the young people's lives and the absence, for virtually all, of a linear trajectory through education to employment and financial independence. Table 1 presents six pen portraits drawn from T2 data, one from each of the pathways, so as to exemplify the combinations of issues the young people were facing.

\section{Fulfilling aspirations?}

The extent to which study participants fulfilled their one-year plans between $\mathrm{T} 1$ and $\mathrm{T} 2$ was very mixed. Their accounts are divided into three: those who had fully, partially, and not achieved their goals.

\section{Fully achieved short-term goals}

Of those who had specific short-term hopes and dreams at $\mathrm{T} 1$ and participated at $\mathrm{T} 2$, seven had fully achieved their one-year aspirations. All seven of these young people had short-term aspirations centred on higher education; four had just completed their university degree course and three were in their first year at university. One of those who had completed their undergraduate degree had also achieved her ambition of being accepted onto a masters degree course. These young people might be considered as members of Stein's (2005) 'moving on' group.

\section{Partially achieved short-term goals}

Eight young people had partially achieved their short-term goals between T1 and T2. Gillian had successfully completed her FE college course but had not started at university as she had intended at T1. She stated that she had not received the support she needed from the leaving care team or her family to enable her to maintain two places to live; her flat in her home city and student accommodation away at university, so she had decided against university. Instead, Gillian was working part time in a pub having not been able to find full-time employment. Holly had completed her degree course but had not been able to find employment; she had taken up a voluntary position with a national youth charity, which she hoped might lead to a paid position in the future.

Marco, who had come to the UK as an unaccompanied asylum seeker, had been granted permanent leave to remain in the UK and had successfully completed his FE course but had not been able to find any paid employment. Bara had also been granted permanent leave to remain in the UK but had not completed his education course, having withdrawn in order to find a job once he received the legal papers that permitted him to take up employment. Masud and Pamy were 
continuing to do well in their studies but their immigration statuses were still not resolved; this was of particular concern for Pamy as completion of her degree course was dependent on her undertaking a year's work placement, which her current legal status did not permit.

Katie had achieved her short-term goal of completing her A levels but had not secured the grades she needed to study the course of her choice at university. In view of this, she had adjusted her plans and was about to begin a vocational course that she hoped would still lead to career in law. Catriona had also partially achieved her short-term hopes and aspirations, she had full-time employment as she had hoped but in a slightly different field than she had intended at T1, although she was very happy in her role in a preschool rather than as a teaching assistant and was taking an NVQ course alongside her employment:

"I was aiming for teaching assistant but got this job, so it's pre-school assistant, it's really quite similar just a bit younger children. But it's working well and I get on with all the staff and I'm doing my NVQ." [Catriona, age 20, female, White]

Some of this group were 'moving on' in themselves, having adjusted their visions, but others were held back by structural factors such as immigration rules.

\section{Not achieved short-term goals}

Eight young people had not achieved their shortterm aspirations by the $\mathrm{T} 2$ interview. Louise had become very ill during the year between $\mathrm{T} 1$ and $\mathrm{T} 2$ and had to be hospitalised. This meant she had had to drop out of the access course she was taking, meaning her plans to go to university had been seriously delayed:

"I was doing really well until I got ill. ... my grades were good and yeah I was really enjoying it, my attendance was really good as well, like I didn't miss a day and ... I ... got accepted for uni as well. Which was ... really nice, because I would have obviously finished the access course and then I would have gone to uni ... but obviously I've got to repeat the year." [Louise, age 20, female, White]

Two young people had not started at university as they had hoped at T1; Lucy had not been able to secure a place and so had deferred starting university for a year having been accepted on a degree course at a less prestigious institution.
Connor had to postpone attending university due to a complete breakdown in his relationship with his foster carers, which culminated in his foster mother destroying his laptop containing all the work he needed to support his application to university:

"There was a point that I suggested moving out...she didn't like it so she smashed my computer up, my laptop which had all my university work on it, which messed my chances up of going uni. That's why I'm having to take a year out now to get money and then next year go to university. [Connor, age 19, male, Black British]

London had not managed to complete her final year at university due to a combination of loss of motivation and an overwhelming amount of coursework - the result of a restructuring of her degree course that meant an increase in the number of modules that needed to be completed in the final year. She was hoping to be able to re-sit some of her modules during the next academic term but had yet to secure permission to do so. Patrick, who was unemployed at $\mathrm{T} 1$, had sought but been unable to find any form of employment over the course of the study period and was still unemployed at T2. Most of this group were in the group Stein (2005) called 'surviving' with episodes of unemployment and precarity in health and relationships. There were no examples of Stein's third group (strugglers), perhaps because of the sampling strategy, which focused on those with educational promise.

\section{Sense of control over events and \\ decisions in the past year}

To a large extent the young people felt they had control over the events in their lives and articulated their sense of control through asserting that 'it's all down to me'. This often reflected their past childhoods of being alone and responsible for themselves and often younger siblings or parents. They had often, in contrast to their age peers not in care, had sole responsibility for their finances and were living in 'independent accommodation' once they had left care where they were responsible for bills, visitors, tenancy agreements and so on. They were good examples of living what Mike Stein called "accelerated and compressed transitions" to adulthood (Stein, 2005) and of "self-reliance" (Cameron, 2013). Table 2 sets out the young 
people's responses to a question about the realisation of their plans.

Eleven of the young people thought that realising plans was, without reservation, their own responsibility. Twelve were either unsure, thought it was down to them but could see real barriers to achieving their plans or believed realising plans were out of their control, including all those in the 'building a life' pathway and one, Pamy, whose legal status meant she could not get a placement to finish her degree programme. It is noteworthy that all the young people in the 'futures on hold' pathway believed they were themselves responsible for progress, including Louise, whose health issues were serious. Similarly, elevated risk of external locus of control among fostered young people is noted by Wijedasa (2017). 
Table 1. Current activity and support available: six pen portraits at T2

\begin{tabular}{|c|c|c|}
\hline $\begin{array}{l}\text { Pathway } \\
\text { representative }\end{array}$ & $\begin{array}{l}\text { Education/employment/ } \\
\text { voluntary work }\end{array}$ & Emotional and practical support \\
\hline $\begin{array}{l}\text { Traditional A } \\
\text { levellers } \\
\text { Gabrielle }\end{array}$ & $\begin{array}{l}\text { Studying for a BA Social Work; } \\
\text { employed three days a week in a } \\
\text { shop; does some mentoring for social } \\
\text { services when asked; volunteers in a } \\
\text { home for the blind. "They want to } \\
\text { train me to work with them". }\end{array}$ & $\begin{array}{l}\text { Problems obtaining resources from local } \\
\text { authority. Got } £ 500 \text { for desktop computer after } \\
\text { long argument. }\end{array}$ \\
\hline $\begin{array}{l}\text { Alternative } \\
\text { traditional } \\
\text { Finan }\end{array}$ & $\begin{array}{l}\text { In the middle of revision period for } \\
\text { exams. Not sure he will pass. Has to } \\
\text { miss classes to do cash-in-hand work. } \\
\text { "I live day by day", "I cannot set my } \\
\text { mind to do my revisions or finish my } \\
\text { coursework". Voluntary work with } \\
\text { cancer charity. }\end{array}$ & $\begin{array}{l}\text { Uncertain legal status, waiting long time, could } \\
\text { not get student loan or work without papers. } \\
\text { Supported by friends and charities. The leaving } \\
\text { care service terminated support because did not } \\
\text { have correct papers, even though he was in } \\
\text { higher education. Friends helped with tuition } \\
\text { fee. "It's not really too bad, but you don't feel } \\
\text { really comfortable living with friends." }\end{array}$ \\
\hline $\begin{array}{l}\text { Ordinary } \\
\text { young lives } \\
\text { Catriona }\end{array}$ & $\begin{array}{l}\text { Working as preschool assistant and } \\
\text { loves it. Always been involved with } \\
\text { children. Doing NVQ Level } 3 \text { which is } \\
\text { "quite boring and way easier" than A } \\
\text { Levels. Did outward bound course and } \\
\text { got nominated for a special needs } \\
\text { award. Saved up for half the cost. } \\
\text { Finished Duke of Edinburgh awards. } \\
\text { Attends gym and dance classes. }\end{array}$ & $\begin{array}{l}\text { Same accommodation (as T1) but planning to } \\
\text { move as "desperate". Got in a "mess" with } \\
\text { finances and getting a housing support worker } \\
\text { to help. Contact with family difficult. Leaving } \\
\text { care team "talk rubbish". }\end{array}$ \\
\hline $\begin{array}{l}\text { Futures on } \\
\text { hold } \\
\text { Alex }\end{array}$ & $\begin{array}{l}\text { Working full time in council nursery as } \\
\text { assistant gardener. Secure, good job } \\
\text { but poor pay. Left degree course in } \\
\text { computing to go into gardening and } \\
\text { says it was the right decision. }\end{array}$ & $\begin{array}{l}\text { Breaking up with wife as "fed up with her rules". } \\
\text { We "reinforce each other's negative sides". It } \\
\text { was my decision and I should have stood up for } \\
\text { myself more. Contact with family quite often but } \\
\text { not foster carers. }\end{array}$ \\
\hline $\begin{array}{l}\text { Home-based } \\
\text { locals } \\
\text { Patrick }\end{array}$ & $\begin{array}{l}\text { Is searching for a job after having } \\
\text { moved into a bungalow. No one is } \\
\text { hiring in his area. No hobbies. }\end{array}$ & $\begin{array}{l}\text { Has regular family contact. Some contact with } \\
\text { ex-foster carer, and with leaving care worker. }\end{array}$ \\
\hline $\begin{array}{l}\text { Building a life } \\
\text { Mervyn }\end{array}$ & $\begin{array}{l}\text { Starting new job with a food company } \\
\text { three days a week. Studying for Level } \\
2 \text { BTEC diploma in web design three } \\
\text { days a week. Voluntary work with } \\
\text { disabled person, of which he said: "I } \\
\text { do it because I think I will need it } \\
\text { when I'm older". "I'm so busy at the } \\
\text { moment I wanted to just concentrate } \\
\text { on my study." }\end{array}$ & $\begin{array}{l}\text { Legal status uncertain; case with Home Office } \\
\text { for some time. Had support letters from council } \\
\text { and did presentation for refugees. No help from } \\
\text { leaving care service: "my social services were a } \\
\text { bit racist"; "I had to leave house because council } \\
\text { would not pay rent. I was earning more than } \\
\text { [the limit]." "They used to pay me } f 21 \text { for the } \\
\text { bus money and they cut it while I'm still in } \\
\text { college." "There was an argument between local } \\
\text { authorities about who was responsible for } \\
\text { helping me. I was homeless for three } \\
\text { months/couch surfing with friends." }\end{array}$ \\
\hline
\end{tabular}


Table 2. T2: Young people's realisation of plans and sense of control

\begin{tabular}{|c|c|c|}
\hline Pathway & Id & How much is realising your plans down to you and how much is outside your control? \\
\hline \multirow{8}{*}{$\begin{array}{l}\text { Traditional } \\
\text { A leveller }\end{array}$} & Barnaby & Much more in control than previously. Making positive choices. Has finished university and is confident about plans to make a living. \\
\hline & Holly & "It's quite in my control but not at the same time. I'm just not sure". \\
\hline & London & $\begin{array}{l}\text { "Maybe it's all my fault [not completing university this year] and that's fine as well, I don't really know, not graduating this year was a } \\
\text { plan, I don't look at it as [if] I'm never going to graduate. I had no problems doing GCSE maths over and over again to get the desired } \\
\text { result that I believe I should achieve. I don't want to look at it as a mistake ... it's just a deviation off the set plan". }\end{array}$ \\
\hline & Frazzle & $\begin{array}{l}\text { "I am firmly set on what I want to do [complete university course]. It's down to me, nobody can make me do a degree, I want to help } \\
\text { people to resolve issues. Took me years to get over my issues... mum dying to realise there's more to life than doing nothing". }\end{array}$ \\
\hline & Tom & $\begin{array}{l}\text { "I think I'm doing well. I am fed up with tutor at uni. Uni is my focus at the moment. You don't know where to go for help, where to go } \\
\text { and ask for help. It's very difficult to rent [equipment for course], they cost a lot of money. And having no support, you can't actually } \\
\text { afford to rent it." }\end{array}$ \\
\hline & Lucy & $\begin{array}{l}\text { "Had to fight hard to get into university. Filled in form on my own. Rely on myself completely. Just want to focus on completing } \\
\text { university. Will sort out finance. It's all down to me." }\end{array}$ \\
\hline & Honey & $\begin{array}{l}\text { "Yes, it's very much down to me, needed good grades, studied hard, got into [univ] to do biomedical sciences. Application for right to } \\
\text { remain pending for two years; can't do anything about that, can't travel. Confident that status will be made permanent but just need to } \\
\text { wait." }\end{array}$ \\
\hline & Gabrielle & $\begin{array}{l}\text { "It's down to me, that's how it has always been, and who I am today. Being put in care and taken from my siblings at such a young age, } \\
\text { I was forced, I had to fend for myself, sort out my own problems, that's just how it is. Once you get your own place its yahoo, but there } \\
\text { is no one, literally no one there. You are on your own." }\end{array}$ \\
\hline \multirow[t]{4}{*}{$\begin{array}{l}\text { Alternative } \\
\text { traditional }\end{array}$} & Sheila & $\begin{array}{l}\text { "Things going well, nothing has not worked out. All help was stopped when leaving care manager changed and things were tight } \\
\text { financially but I managed." }\end{array}$ \\
\hline & Bebeto & $\begin{array}{l}\text { "I think it mostly relies on me. But maybe family and friends support morally, not financially, but most of it relies on me [searching] for } \\
\text { the right course. I'm not enjoying Business Studies at all, I'll have to find another way. I would like to move. I don't want to live in a flat } \\
\text { anymore." }\end{array}$ \\
\hline & Finan & $\begin{array}{l}\text { "To get the best grades in my degree is one of my priorities. Short-term plan is to pass exams, get work experience in financial sector. If } \\
\text { I get papers, I will get a student loan to help me financially, get work experience and get a job. Any evening job or anything. No more } \\
\text { studying, I want to work. It's not just the [immigration] papers, I really have to work hard on my education and work experience. And I } \\
\text { have to have contacts from that as well, you know, where I could work." }\end{array}$ \\
\hline & Pamy & $\begin{array}{l}\text { "Outside my control. I didn't get a placement because of my status, my current situation. Main goal is education ... to be successful in } \\
\text { my degree." }\end{array}$ \\
\hline
\end{tabular}




\section{Table 2 (cont.).}

\begin{tabular}{|c|c|c|}
\hline \multirow[t]{2}{*}{$\begin{array}{l}\text { Ordinary } \\
\text { young } \\
\text { lives }\end{array}$} & Jane & $\begin{array}{l}\text { Gave up plans to be a midwife as did not fit with childcare arrangements. Unsettling time following separation from boyfriend led to } \\
\text { postponing university. Gave up plans to move cities because of practical constraints - access to housing and childcare and leaving care } \\
\text { support only available in home town. }\end{array}$ \\
\hline & Catriona & "I can do my best. It's up to others to decide if I can be accepted". \\
\hline \multirow[t]{4}{*}{$\begin{array}{l}\text { Futures on } \\
\text { hold }\end{array}$} & Louise & $\begin{array}{l}\text { "It's a bit of both really. I mean obviously psychiatric illness is out of my control, but I can learn to deal with it and I can learn to live } \\
\text { with it. The only thing holding me back at the moment is the illnesses." }\end{array}$ \\
\hline & Donna & $\begin{array}{l}\text { "I'm still in touch with [leaving care worker] but I don't need to discuss my plans [to return to college, get a job, arrange childcare] with } \\
\text { anybody." }\end{array}$ \\
\hline & Conor & "Very determined [to achieve future goals]." \\
\hline & Alex & $\begin{array}{l}\text { Planned to leave computer course and did so. Got job as apprentice gardener and now trainee. "It was my decision to break up with } \\
\text { [wife]. I just accepted it for a long time. I should have stood up for myself more. A lot of it [achieving future plans] is up to me because } \\
\text { I'm willing to put in the effort." }\end{array}$ \\
\hline $\begin{array}{l}\text { Home- } \\
\text { based } \\
\text { local }\end{array}$ & Patrick & "Plans [housing, contact with family, employment] have worked out alright". \\
\hline \multirow[t]{4}{*}{$\begin{array}{l}\text { Building a } \\
\text { life }\end{array}$} & Mervyn & $\begin{array}{l}\text { "I don't know. I'm not really chasing it [Home Office application], but my solicitor sometimes phones me. I had support from councils, } \\
\text { they wrote support letters. I did presentations for refugees. They say you gave so much to this country, so I don't know why that they } \\
\text { do that to me... I went to MP. I'm still waiting." }\end{array}$ \\
\hline & Bara & $\begin{array}{l}\text { "I'm just waiting....still waiting just Home Office give me permission or refuse me. Life will be alright. Now it's very different from two } \\
\text { years ago. I didn't know so much. Slowly, slowly, it will be alright." }\end{array}$ \\
\hline & Marco & $\begin{array}{l}\text { "It's [completing course] not down to me: I can't do the technical English classes only general vocabulary; there are no technical } \\
\text { language classes at all." Feels a bit trapped. }\end{array}$ \\
\hline & Masud & "Just now no passport, not a lot of choices. Will see about higher education after [completing] Level 3 course." \\
\hline
\end{tabular}




\section{'It's down to me' - what does it mean?}

That so many of the young people thought of themselves as responsible for achieving their own aspirations might be seen to fit the individualisation thesis with its articulation of a new freedom, to constantly negotiate forms of identity and selfconcept without the constraints of being viewed through the lenses of the past. In this understanding, the individual is the basic unit of social reproduction (Beck \& Willms, 2004), and the individual has to make choices about their lives, a narrative that makes sense to them.

According to Beck, normative barriers that structured choice-making in the past have begun to dissolve, or have dissolved, as have expected roles and distinctions along gender, ethnic and class lines. Beck refers to a 'fluid structure' of late modern society, where individual agency is perhaps the most significant organising factor. Beck argues that individualisation does not mean freedom to choose or complete isolation in choice-making, although these are possibilities. More often, individualisation means that the responsibility of choice-making rests with the individual, who must negotiate, inform themselves, and take decisions that contribute to the construction of their own life. Beck argues that key domains for individualisation are the family, and the fragmentation and diversity of family forms is some evidence for this, and education, spurred on by the mass expansion of higher education, with ideals of pursuing one's own goals (Beck \& Willms, 2004).

But individualisation also brings insecurities and constraints of its own, particularly for those with few negotiating skills or material resources. There are risks. One risk is that making choices happens with few certainties such as previous experience in the family, or cultural traditions, on which to base decision-making, so generating insecurities in the individual (Bryderup, 2010). This 'risky freedom' (Beck and Beck-Gernsheim, 2002), where young people hold intense responsibility for their own lives, is often reinforced by social policies that focus on individual plans and outcomes rather than state or social responsibility for their wellbeing. England's 'targeted approach' (Hauari with Cameron, 2014) is a good example of this individualist strategy, as is the process of preparing for leaving care through a succession of individually oriented planning meetings from the age of 15 years. For the young people in the YiPPEE study, choice-making was, in part, inspired by personal determination, but also channelled by the expectations of professionals around them, as well as financial resources to allow them to take up places at universities. It is unlikely so many would have been talking in terms of higher education ambitions prior to the introduction of policies and practices to support this, including bursaries designed to enable take up of places.

Individualisation is taking place in an advanced neo-liberal society in which young people are increasingly positioned as entrepreneurial subjects (Smith, 2011) whose agency is linked to instrumental knowledge and expertise (Dahlberg \& Moss, 2005). No longer passive recipients, young people are participants in constructing and constituting their achievements and wellbeing, in ways that are amenable to measurement, such as progress in education or examination certificates (Smith, 2011). Kryger (2004: p154-5) argues that this represents a shift whereby 'children [like adults] are not only obliged to shape their own learning, but also to take responsibility for this shaping'. In this view, young people are seen as 'autonomous choosers' (Marshall, 1996), and lack of engagement through 'choice' or material disadvantage or structural barriers in 'choosing' is rendered problematic or even a personal or familial failing (Smith, 2011).

These shifting expectations of what it is to be a learner, or a young person, suggest that the discourse of 'it's down to me' would be very familiar to young people leaving care from everyday talk among peer groups, reinforced by the messages of professionals in education and in leaving care services, and, often, lack of support for realising educational plans from foster carers and/or parents.

However, the experience of individualisation is not necessarily equal, across social class, cultural identity or country borders and the individualisation thesis is somewhat optimistic (Vandenbroeck, 2007). That just $7 \%$ of young people from a public care background attend higher education, about a seventh of the proportion of young people overall (DfE 2017b), reinforces the long-standing association between social class, parental support and educational attainment in the UK (Halsey, et al., 1980; Desforges \& Abouchaar, 2003). The experiences of the educationally 'promising' young people in the YiPPEE study was that over one year, only a minority had fully achieved their short-term 
goals, suggesting that while they have an 'education ethic' (Cameron, 2013), the practical barriers of following it through remain powerful despite policy intentions. For some, these barriers are absolute, such as long delays in waiting for Home Office decisions on their right to remain in the UK, for others it was practical constraints such as accessing childcare or housing, or resolving health problems. The thesis of individualisation, although a prominent discourse in the ethos of selfresponsibility and self-reliance that pervaded accounts of how to achieve ambitions, does not account for the practical barriers, and lack of, or certainly mixed, progress that many young people experienced between $\mathrm{T} 1$ and $\mathrm{T} 2$. It is rarely enough to believe oneself to be responsible and envision oneself as self-reliant in order to achieve goals. In some cases, ascribing self-reliance may in fact be to reject practical and emotional support and in consequence to delay the achievement of goals. Donna, for example, said "I don't need to discuss my plans with anybody". This highly agentic view of herself and the complex practical arrangements she needed to secure further study may reflect a habitual necessity through childhood and a lack of responsiveness from professionals and family members as well as a growing societal discourse of responsibility for choice-making.

\section{Conclusion}

YiPPEE study participants were not representative of all care leavers. At age 16, they had acquired some educational qualifications and had shown the potential for further study, while around $30 \%$ of care leavers do not acquire any qualifications (DFE, 2010). However, such potential was not always followed through either in postcompulsory educational pathways nor in the realisation of short-term goals. Only those with traditional A levels or who were pursuing nonacademic interests in their home communities had a sense that their goals might reasonably be realised. Even among these young people, who were largely of the view that securing their futures was down to them, there were those who perceived barriers to attaining their goals.

The perception that 'it's down to me' for young people from public care backgrounds is not just a reflection of individualised discourses of ambition, supported by individualised care planning, and normative societal expectations of driving one's own narrative through education and eventual employment, important as these are. It is also a reflection of competing, and powerful, policy and practice influences, as well as family backgrounds. For those who had arrived as unaccompanied asylum seekers, realising plans was often seen as out of their own control, putting them in an official limbo, wherein it was difficult to complete their educational programmes, or obtain work, forcing some to rely on friends and the informal economy for survival. For other young people, the narrative of 'it's down to me' was still strong but emotional and practical obstacles, such as relationship break up, or overload of module assignments, meant a reshaping of their plans and aspirations.

\section{Acknowledgements}

The YiPPEE project (2008-2010) was funded by the European Union's Seventh Framework programme (Socio-Economic Sciences and Humanities, No 217297). The author wishes to acknowledge the contribution of all partners and project researchers, especially the team in England: Sonia Jackson, Hanan Hauari, Katie Hollingworth. The views expressed are those of the author and not necessarily those of other partners or of the European Union. The author would especially like to thank the young people, foster carers and other contributors to the research for their time, insights and thoughtfulness in addressing this very important issue. Without their willingness and interest, this paper would not have been possible. Three anonymous reviewers also helped improve the paper. 


\section{References}

Ball, S., Maguire, M., \& Macrae, S. (2000). Choice, pathways and transitions post-16: New youth, new economies in the global city. London: RoutledgeFalmer.

Bebbington, A. \& Miles, J. (1989). The background of children who enter local authority care. British Journal of Social Work, 19(1) 349-368. https://doi.org/10.1093/bjsw/19.5.349

Beck, U. \& Beck-Gernsheim, E. (2002). Individualization: Institutionalized individualism and its social and political consequences. London: Sage.

Beck, U. \& Willms, J. (2004). 'Conversation 2: Individualization' in J. Willms (Ed.) Conversations with Ulrich Beck. Cambridge: Polity Press.

Berridge, D. (2017). The education of children in care: Agency and resilience. Children and Youth Services Review, 77, 86-93. https://doi.org/10.1016/j.childyouth.2017.04.004

Brannen, J. \& Nilsen, A. (2002). Young people's time perspectives: From youth to adulthood. Sociology, 36(3), 513-537. https://doi.org/10.1177/0038038502036003002

Bryderup, I. (2010). YiPPEE Danish National Report. Out of print. Contact author.

Cameron, C., Hollingworth, K., Schoon, I., van Santen, E., Schröer, W., Ristikari, T., Heino, T., \& Pekkarinen, E. (submitted). Care leavers in early adulthood: how do they fare in England, Finland and Germany?

Cameron, C. (2013). Education and self-reliance among care leavers, in S. Jackson (ed) Pathways through education for young people in care: Ideas from research and practice. London: British Association of Adoption and Fostering.

Cameron, C., Jackson, S., Hauari, H. \& Hollingworth, K. (2012). Continuing educational participation among children in care in five countries: some issues of social class. Journal of Education Policy, 27(3), 387399. https://doi.org/10.1080/02680939.2011.644811

Courtney, M. Okpych, N., Charles, P., Mikell, D., Stevenson, B., Park, K., Kindle, B., Harty, J. \& Feng, H. (2016). Findings from the California Youth Transitions to Adulthood Study (CalYOUTH): Conditions of youth at age 19. Chicago, IL: Chapin Hall at the University of Chicago.

Dahlberg, G. \& Moss, P. (2005). Ethics and Politics in Early Childhood Education, Abingdon: RoutledgeFalmer.

Department for Education (2017). Outcomes for children looked after by local authorities in England as at 31 March 2016. SFR 12/2017.

Department for Education (2016). Participation rates in higher education: Academic years 2006/20072014/2015 (Provisional), SFR45/2016.

Department for Education (2010). Outcomes for children looked after by local authorities in England as at 31 March 2010. SFR 38/2010. Available at https://www.gov.uk/government/uploads/system/uploads/attachment data/file/218835/sfr38 202 $\underline{010 \mathrm{v} 4 . \mathrm{pdf}}$

Desforges, C. \& Abouchaar, A. (2003). The impact of parental involvement, parental support and family education on pupil achievement and adjustment. London: DFES Research Report 433.

Furlong, A. (2009). Revisiting transitional metaphors: Reproducing inequalities under the conditions of late modernity. Journal of Education and Work, 22, 343-53.

https://doi.org/10.1080/13639080903453979

Geiger, J. \& Beltran, S. (2017). Experiences and outcomes of foster care alumni in postsecondary education: A review of the literature. Children and Youth Services Review 79, 186-197. https://doi.org/10.1016/j.childyouth.2017.06.023

Halsey, A. H., Heath, A. F. \& Ridge, J. M. (1980). Origins and destinations: Family, class and education in modern Britain. Oxford: Clarendon Press.

Harvey, A., Campbell, P., Andrewartha, L., Wilson, J. \& Goodwin-Burns, P. (2017). Recruiting and supporting care leavers in Australian higher education. Report for the Australian Government Department of Education and Training. Melbourne: Centre for Higher Education Equity and Diversity Research, La Trobe University. 
Hauari, H. with Cameron, C. (2014). England: A targeted approach, in S. Jackson \& C. Cameron. Improving the participation of young people in care in further and higher education: European research and practice. London: Jessica Kingsley Publishers.

Henderson, S., Holland, J., McGrellis, S., Sharpe, S. \& Thomson, R. (2007). Inventing adulthoods: A biographical approach to youth transitions. London: Sage.

Jackson, S. \& Cameron, C. (2014). Improving the participation of young people in care in further and higher education: European research and practice. London: Jessica Kingsley Publishers.

Jackson, S. \& Sachdev, D. (2001) Better education, better futures: Research, practice and the views of young people in public care. Ilford: Barnardo's.

Jerrim, J. (undated). Family background and access to 'high status' universities. The Sutton Trust. Available at http://www.suttontrust.com/wp-content/uploads/2014/08/john-jerrim-report-final-4.pdf accessed 9 July 2017.

Kryger, N. (2004). Childhood and new learning in a Nordic context. In H. Brembeck, B. Johansson and J. Kampmann (eds) Beyond the competent child: Exploring contemporary childhood in the Nordic Welfare Societies. Roskilde: Roskilde University Press, 165-189.

Marshall, J. (1996). The autonomous chooser and reforms in education. Studies in Philosophy and Education, 15, 1-2, 89-96. https://doi.org/10.1007/BF00367517

Sebba, J., Berridge, D., Strand, S., Thomas, S., Luke, N., Fletcher, J., Bell, K., Sinclair, I. \& O'Higgins, A. (2015). The educational progress of looked after children in England: Linking care and educational data. Oxford: The Rees Centre Oxford.

Smith, K. (2011). Producing governable subjects: Images of childhood old and new. Childhood, 19(1), 24-37. https://doi.org/10.1177/0907568211401434

Stein, M. (2005). Resilience and young people leaving care: Overcoming the odds. York: Joseph Rowntree Foundation. Available at https://www.jrf.org.uk/report/resilience-and-young-people-leaving-care accessed 9 July 2017.

Vandenbroeck, M. (2007). Beyond anti-bias education: changing conceptions of diversity and equity in European early childhood education. European Early Childhood Education Research Journal, 15(1), 21-35. https://doi.org/10.1080/13502930601046604

Wigfall, V. \& Cameron, C. (2006). Promoting young people's participation in research in E. Chase, A. Simon and S. Jackson (Eds.) Young people in care and after: A positive perspective. London: Routledge.

Wijedasa, D. (2017). 'People like me don't have much of a chance in life': comparing the locus of control of young people in foster care with that of adoptees, children from disadvantaged backgrounds and children in the general population. Adoption And Fostering, 41(7), 5-17.

https://doi.org/10.1177/0308575916684299 